\title{
EXISTENCE AND UNIQUENESS OF A POSITIVE SOLUTION TO GENERALIZED NONLOCAL THERMISTOR PROBLEMS WITH FRACTIONAL-ORDER DERIVATIVES
}

\author{
Moulay Rchid Sidi Ammi And Delfim F. M. TORRES
}

Abstract. In this work we study a generalized nonlocal thermistor problem with fractionalorder Riemann-Liouville derivative. Making use of fixed-point theory, we obtain existence and uniqueness of a positive solution.

Mathematics subject classification (2010): 26A33, 35B09, 45M20.

Keywords and phrases: Riemann-Liouville derivatives, nonlocal thermistor problem, fixed point theorem, positive solution.

\section{REFERENCES}

[1] S. ABBAS, Existence of solutions to fractional order ordinary and delay differential equations and applications, Electron. J. Differ. Equ., 9 (2011), 1-11.

[2] R. P. AgARwal, M. Benchohra AND S. HAMANi, Boundary value problems for fractional differential equations, Georgian Math. J., 16, 3 (2009), 401-411.

[3] R. P. AgARWAL, Y. ZHOU AND Y. HE, Existence of fractional neutral functional differential equations, Comput. Math. Appl., 59, 3 (2010), 1095-1100.

[4] S. N. AntontSEV AND M. ChIPOT, The thermistor problem: existence, smoothness uniqueness, blowup, SIAM J. Math. Anal., 25, 4 (1994), 1128-1156.

[5] G. CimatTi, Existence of weak solutions for the nonstationary problem of the joule heating of a conductor, Ann. Mat. Pura Appl., (4) 162 (1992), 33-42.

[6] L. Gaul, P. Klein And S. Kempfle, Damping description involving fractional operators, Mech. Syst. Signal Process., 5 (1991), 81-88.

[7] C. GiannANTONI, The problem of the initial conditions and their physical meaning in linear differential equations of fractional order, Appl. Math. Comput., 141, 1 (2003), 87-102.

[8] R. Hilfer, Applications of fractional calculus in physics, World Sci. Publishing, River Edge, NJ, 2000.

[9] S. D. HowisOn, J. F. ROdRIGUES AND M. SHILloR, Stationary solutions to the thermistor problem, J. Math. Anal. Appl., 174, 2 (1993), 573-588.

[10] A. A. Kilbas, H. M. SRivastava And J. J. Trujillo, Theory and applications of fractional differential equations, North-Holland Mathematics Studies, 204, Elsevier, Amsterdam, 2006.

[11] K. KwoK, Complete guide to semiconductor devices, McGraw-Hill, New york, 1995.

[12] A. A. LACEY, Thermal runaway in a non-local problem modelling Ohmic heating. II. General proof of blow-up and asymptotics of runaway, European J. Appl. Math., 6, 3 (1995), 201-224.

[13] E. D. MACLEN, Thermistors, Electrochemical publication, Glasgow, 1979.

[14] K. S. Miller AND B. Ross, An introduction to the fractional calculus and fractional differential equations, A Wiley-Interscience Publication, Wiley, New York, 1993.

[15] D. Mozyrs Ka And D. F. M. Torres, Modified optimal energy and initial memory of fractional continuous-time linear systems, Signal Process., 91, 3 (2011), 379-385.

[16] I. Podlubny, Fractional differential equations, Mathematics in Science and Engineering, 198, Academic Press, San Diego, CA, 1999.

[17] I. Podlubny and A. M. A. El-SAyed, On two definitions of fractional calculus, preprint UEF (ISBN 80-7099-252-2), Solvak Academy of Science-Institute of Experimental Phys (1996), 03-06. 
[18] J. Sabatier, O. P. Agrawal, J. A. Tenreiro Machado, Advances in fractional calculus, Springer, Dordrecht, 2007.

[19] S. G. SAMKO, A. A. KilbAS AND O. I. MARICHEV, Fractional integrals and derivatives, translated from the 1987 Russian original, Gordon and Breach, Yverdon, 1993.

[20] H. M. SRIVASTAVA AND R. K. SAXENA, Operators of fractional integration and their applications, Appl. Math. Comput., 118, 1 (2001), 1-52.

[21] D. E. TZAnEtis, Blow-up of radially symmetric solutions of a non-local problem modelling Ohmic heating, Electron. J. Differential Equations, 2002, 11 (2002), 26 pp. 